\title{
O TERMO INICIAL DOS JUROS MORATÓRIOS NA RESPONSABILIDADE CIVIL: UMA ANÁLISE A PARTIR DA TEORIA DA IRRADIAÇÃO
}

\section{*Diego José Baldissera \\ ** Celso Hiroshi Iocohama}

RESUMO: a teoria da irradiação aborda a eficácia jurídica a partir de um estudo de como os fatos ingressam no mundo jurídico, tornando-se fatos jurídicos. Sobre o termo inicial dos juros moratórios na responsabilidade civil, a teoria da irradiação revela um equívoco do Código Civil, que estabelece termos iniciais diferentes, conforme se trate de responsabilidade contratual ou extracontratual. Entretanto, existem situações em que o mesmo ato ilícito pode ser uma violação do contrato e da lei. Nessas hipóteses, pela da teoria da irradiação, os juros não deveriam incidir em momentos distintos, porque o fato jurídico seria o mesmo.

PALAVRAS-CHAVE: contratual; extracontratual; ato ilícito; fato jurídico; lex aquilia

\section{THE INITIAL TERM OF MORATORIUM INTEREST IN THE CIVIL RESPONSIBILITY: AN ANALYSIS STARTING FROM IRRADIATION THEORY}

\begin{abstract}
: the irradiation theory approaches the juridical efficiency starting from a study of how the facts are inserted in the juridical world, becoming juridical facts. About the initial term of the moratorium interest rates in the civil responsibility, such theory reveals a misconception within the Civil code, that establishes different initial terms in the case of contractual or extra contractual responsibility. However, there are situations in which the same illicit act can be a violation of the contract and of the law. In such hypothesis, the interest shouldn't focus in distinct moments, because the juridical fact would be the same.
\end{abstract}

KEYWORDS: contractual; extra contractual; illicit act; juridical fact; lex aquilia

\section{INTRODUÇÃO}

A responsabilidade civil é matéria vastíssima. Comporta várias espécies de classificação, cada qual bastante detalhada. Assim, o esgotamento do assunto, além de não ter sido pretendido, seria impossível. Focou-se apenas nos pontos julgados essenciais à construção do raciocínio a ser defendido.

\footnotetext{
* Especialista em Direito Previdenciário pela Universidade Paranaense. Mestrando em Direito Processual e Cidadania pela Universidade Paranaense.

** Mestre em Direito das Relações Sociais pela Universidade Estadual de Londrina. Doutor em Direito pela Pontifícia Universidade Católica de São Paulo. Doutor em Educação pela Universidade de São Paulo. Coordenador do Programa de Mestrado em Direito Processual Civil e Cidadania da Universidade Paranaense.
} 
Dentre as mais importantes, e, consequentemente, as mais discutidas classificações da responsabilidade civil, tem-se sua subdivisão em contratual e extracontratual ou aquiliana; a primeira decorrente de violação de um contrato, e a segunda decorrente da violação da lei, seja de uma disposição legal específica ou do chamado dever de a ninguém lesar.

As diferenças existentes entre uma e outra, contudo, são pontuais. A responsabilidade é um gênero, cujas espécies fundam-se nas mesmas premissas. As classificações servem para melhor estudar, sistematizar e regulamentar a matéria. Não significam que, por exemplo, a responsabilidade contratual e a responsabilidade extracontratual sejam coisas absolutamente distintas. No entanto, mesmo assim, o Código Civil regulamenta determinados pontos de forma diferente, como é o caso do termo inicial dos juros de mora, numa e noutra espécie de responsabilidade.

Esse tratamento diferenciado é bastante questionável, destacadamente pela possibilidade de que, em determinadas situações, o agente, por meio do mesmo ato ilícito, pode causar danos a pessoa com a qual mantenha relação contratual, e a pessoa com a qual não mantenha relação contratual. Noutras palavras, do mesmo ato ilícito, podem decorrer responsabilidade contratual e aquiliana. Nessa situação, especialmente, a incidência dos juros moratórios em momentos distintos, para uma e outra vítima, pode ser combatida com base em alguns argumentos.

Um desses argumentos é a teoria da irradiação, também chamada de teoria do fato jurídico, desenvolvida por Pontes de Miranda.

Essa teoria trata, em resumo, do caminho a ser percorrido até que se chegue à eficácia jurídica. Para tanto, Pontes de Miranda percorre um caminho iniciado com o suporte fático, sua entrada no mundo jurídico, e, ao final, sua eficácia, à qual o Autor chama de irradiação de efeitos.

O presente trabalho, elaborado mediante pesquisa bibliográfica, pretende analisar o tratamento diferenciado dispensado pelo Código Civil à incidência de juros moratórios na responsabilidade contratual e aquiliana decorrentes do mesmo ato ilícito. Para tanto, abordou-se os pontos elementares da responsabilidade civil, com enfoque em sua classificação em contratual e aquiliana, e a teoria da irradiação, de Pontes de Miranda. 


\section{BREVES CONSIDERAÇÕES HISTÓRICAS SOBRE A RESPONSABILIDADE} CIVIL

Assim como muitos dos institutos, principalmente do Direito Civil moderno, a responsabilidade civil remonta ao antigo Direito Romano. Responsabilidade vem do latim respondere, “[...] querendo dizer aproximadamente o ter alguém se constituído garantidor de algo", explica Serpa Lopes (1964, p. 187). Na fórmula da stipulatio romana, prossegue o Autor, a obrigação era contraída mediante a resposta spondeo à pergunta dare mihi spondes.

Nesse remoto período, entretanto, a ideia de responsabilidade civil era substancialmente diferente do que é hoje. A responsabilidade civil que se conhece hoje, via de regra, é fundada, como se verá oportunamente, na culpa. No entanto, nos primórdios da sociedade, não se falava em responsabilidade civil subjetiva, isto é, responsabilidade civil que pressupõe a demonstração de culpa do agente. A prática de atos ilícitos autorizava a reação imediata do ofendido, em uma verdadeira vingança privada, que, "“[...] como modo de compensar o dano, era contraproducente; em verdade, com ela não havia reparação alguma, porém duplo dano, redobrada lesão, a da vítima e a de seu ofensor, depois de punido", destacam Monteiro, Maluf e Silva (2010, p. 555). A finalidade era apenas devolver o mal recebido, diz Alvim (1980).

Não tardou, portanto, a percepção de que tal forma de responsabilidade civil não servia ao ofendido, uma vez que não lhe reparava coisa alguma. A antiga vindita, então, é substituída pela reparação econômica, em princípio, voluntária; posteriormente, obrigatória; e, por fim, tarifada, “[...] quando, então, o ofensor paga um tanto por membro roto, por morte de um homem livre ou de um escravo [...]" (GONÇALVES, 2014, p. 25), como ocorria, por exemplo, na Lei das XII Tábuas.

Nessa época, ainda não havia distinção entre responsabilidade civil e penal. Simplesmente, regulamentava-se a sanção a ser aplicada contra aquele que cometesse algum tipo de ilícito, como esclarece Santos (2013), muito embora houvesse a distinção entre delitos públicos e privados, chamados, respectivamente, de crimen e maleficium.

A responsabilidade civil à semelhança do que se conhece hoje surgiu no século 3 a.C., com a Lex Aquilia, nominada em homenagem ao tribuno Aquilo, e origem do termo culpa aquiliana, quando se fala na responsabilidade civil extracontratual. Embora já no 
período da Lei das XII Tábuas tivesse predominado a ideia de reparação em pecúnia, a Lex Aquilia reforçou essa forma de reparação, além de, para alguns, ter abordado, pela primeira vez, a valoração do elemento subjetivo, isto é, a análise da culpa do agente. Por essas razões é que se considera a Lex Aquilia como uma espécie de embrião da responsabilidade civil nos moldes hoje conhecidos. A questão, no entanto, é controvertida. Além dos que defendem que a Lex Aquilia exigia a demonstração de culpa, para que houvesse responsabilidade civil, para outros, a culpa, enquanto elemento autônomo, surgiu somente no posterior direito Justinianeu, sendo que a Lex Aquilia apenas mencionava a culpa, havendo, ainda, posicionamentos no sentido de que a Lex Aquilia sequer falava em culpa.

Posteriormente, vieram as Institutas do Imperador Justiniano, que também trouxeram importantes elementos para a regulamentação da responsabilidade civil, como, por exemplo, a regulamentação da imperícia como espécie de culpa e a responsabilização da culpa levíssima, como aponta Limongi França (2011). Nesse período, portanto, pode-se dizer que não havia mais dúvida: a culpa passara a ser requisito da responsabilização civil.

Também os Digestos foram elaborados sob forte influência da Lex Aquilia, sendo que, de acordo com Limongi França (2011), cinquenta e sete fragmentos da Lex Aquilia foram transcritos nos Digestos. Mas esta compilação também teve sua importância, regulamentando, por exemplo, a responsabilidade dos professores, dos médicos e dos que praticassem jogos perigosos. Sua principal contribuição, no entanto, foi o que Limongi França (2011) chamou de "[...] primeiras manifestações da teoria do risco ou da indenização objetiva", identificadas, por exemplo, no fragmento que responsabilizava o transportador que carregasse mais carga do que deveria.

No Direito Ibérico, o Código Visigótico e as Sete Partidas de D. Afonso tratavam da responsabilidade aquiliana, mas sem inovações significantes. O mesmo se pode dizer das Ordenações, que foram as primeiras legislações a viger no Brasil.

O tema permaneceu sem grandes alterações até, aproximadamente, a metade do século passado. No Código Civil de 1916, havia um só artigo dedicado à responsabilidade civil: o artigo 159. Só havia, portanto, responsabilidade subjetiva ${ }^{1}$. Daí Cavalieri Filho ter escrito que "[...] não era preciso estudar responsabilidade civil, bastava conhecer o art. 159” (2014, p. 2). No entanto, conforme dito, em meados do século XX, iniciava-se uma verdadeira revolução em matéria de responsabilidade civil, pelo simples fato de que as

\footnotetext{
${ }^{1}$ Só havia responsabilidade subjetiva no Código Civil. Em leis esparsas, já se falava na responsabilidade objetiva, como, por exemplo, na Lei das Estradas de Ferro, de 1912, lembrada por Cavalieri Filho (2014).
} 
próprias relações sociais, em geral, mas, destacadamente, a indústria, passavam por uma revolução, na época. "O tronco primitivo, o tronco romano, desdobrou-se numa porção de ramos, e a responsabilidade tornou-se todo um mundo jurídico, mundo em movimento, em incessante gestação, sempre a começar [...]”, escreveu Josserand (1941, p. 548), acentuando que "[...] a responsabilidade não se realiza só mais frequentemente que outrora, mas também se realiza de outros modos; apresenta-se com múltiplas faces, desconhecidas da sociedade romana [...]”. A principal herança dessa chamada revolução da responsabilidade civil foi a abertura de espaço às teorias da responsabilidade civil objetiva. “O sistema da culpa provada, estabelecido como cláusula geral no art. 159 do Código Civil de 1916, traduzia com fidelidade o ideário liberalista do século XX”, comenta Cavalieri Filho (2014, p. 5). Rompido esse sistema de absoluto liberalismo, não mais se sustentava a exclusividade da responsabilidade subjetiva.

Essa abertura de espaço para a responsabilidade civil objetiva só operou efeitos significantes, no Brasil, após a Constituição de 1988, “[...] que pacificou a questão da indenização pelo dano moral (art. $5^{\circ}$, incisos V e X) e estendeu, no $\S 6^{\circ}$ do seu art. 37 , a responsabilidade objetiva, tal qual a do Estado, a todos os prestadores de serviços públicos", comenta Cavalieri Filho (2014, p. 5). Muito embora a responsabilidade objetiva já fosse prevista em outras leis esparsas, o art. 37, § $6^{\circ}$, da Constituição de 1988, foi que rompeu de vez com a sistemática até então vigente, “[...] porque a expressão prestadores de serviços públicos abrange uma vasta área do mundo negocial: luz, gás, telefonia, transportes etc." (CAVALIERI FILHO, 2014, p. 5), área esta que, antes da Constituição de 1988, só respondia civilmente por algum dano causado, se houvesse a demonstração de culpa.

A partir da Constituição de 1988, a responsabilidade objetiva ganhou espaço crescente (com o advento do Código de Defesa do Consumidor, em 1990, por exemplo), até ser inserida no próprio Código Civil de 2002.

\section{LINHAS GERAIS SOBRE A RESPONSABILIDADE CIVIL}

A evolução da responsabilidade civil, ocorrida, principalmente, a partir da Constituição de 1988, transferiu o núcleo da matéria da culpa para o dano, como destacam Monteiro, Maluf e Silva (2010). “O interesse em restabelecer o equilíbrio econômico- 
jurídico alterado pelo dano é a causa geradora da responsabilidade civil”, pontua Aguiar Dias (1997, p. 42). Mas o Direito, lecionava Dantas (1979), não pode atuar somente após já ter havido violação ao ordenamento jurídico, cujo principal objetivo é a proteção do lícito e a repressão do ilícito.

A vida em sociedade exige a observância a certos deveres, desde os mais específicos, como, por exemplo, fazer ou deixar de fazer alguma coisa, em virtude de disposição legal ou contratual, até os mais abstratos, englobados no chamado dever geral de não prejudicar ou de não lesar a ninguém, oriundo do brocardo romano neminem laedere.

A violação desses deveres, ditos jurídicos, conceituados por Cavalieri Filho (2014, p. 14), como "[...] a conduta externa de uma pessoa imposta pelo Direito Positivo por exigência da convivência social", resulta no surgimento de um outro dever jurídico: o de reparar o dano. "Há, assim, um dever jurídico originário, chamado por alguns de primário, cuja violação gera um dever jurídico sucessivo, também chamado de secundário, que é o de indenizar o prejuízo", explica Cavalieri Filho (2014, p. 14), que conceitua a responsabilidade civil como "[...] um dever jurídico sucessivo que surge para recompor o dano decorrente da violação de um dever jurídico originário" (2014, p. 14).

Só se fala em responsabilidade civil, portanto, seja subjetiva ou objetiva, quando houver violação de um dever jurídico originário, que nada mais é do que uma obrigação. Daí já se extrai que obrigação e responsabilidade, embora sejam conceitos conexos, não se confundem.

\subsection{Obrigação e responsabilidade}

Para que se possa compreender a responsabilidade civil, um importante passo é diferenciá-la da ideia de obrigação.

De acordo com a lição de Cavalieri Filho (2014), pode-se dizer que, enquanto a obrigação é um dever originário, decorrente de convenção ou lei, a responsabilidade é um dever sucessivo, que vem à tona somente quando e se o dever jurídico originário, isto é, a obrigação, for descumprido. "A responsabilidade é, pois, a consequência jurídica patrimonial do descumprimento da relação obrigacional”, diz Gonçalves (2014, p. 21). 
Essa distinção entre dever jurídico originário e dever jurídico sucessivo corresponde, respectivamente, à distinção entre schuld e haftung, do Direito Alemão, onde schuld é a própria obrigação de realizar determinada prestação, e haftung é o direito de o credor atacar o patrimônio do devedor, se descumprida a obrigação.

Ao contrário do que se possa pensar à primeira vista, a diferenciação não é puramente teórica. "Sempre que quisermos saber quem é o responsável teremos que identificar aquele a quem a lei imputou a obrigação [...]", ensina Cavalieri Filho (2014, p. 15). Sabidamente, existem casos de responsabilidade sem obrigação. Entretanto, mesmo nesses casos, para identificar o responsável, é imprescindível que se identifique o obrigado, porque o responsável sempre é alguém que possui uma relação com o obrigado; nunca o responsável é alguém totalmente estranho à obrigação. O clássico exemplo de responsabilidade sem obrigação é o do fiador. A fiança é um contrato acessório entre o fiador e o devedor principal (obrigado). Consequentemente, mesmo nesse caso, em que o responsável não é o obrigado, a identificação daquele só é possível com a identificação deste.

Da mesma forma que se pode falar em responsabilidade sem obrigação, a recíproca também é verdadeira, como nos tradicionais exemplos das dívidas prescritas e das dívidas de jogo. "O devedor, nestes casos, não pode ser condenado a cumprir a prestação, isto é, ser responsabilizado, embora continue devedor" (GONÇALVES, 2014, p. 21). No caso da dívida prescrita, porque o credor não mais dispõe da ferramenta processual para exigir o crédito, e, no caso da dívida de jogo, porque a lei veda a própria exigibilidade.

O Código Civil deixa clara essa distinção, na redação do art. 389: "Não cumprida a obrigação, responde o devedor por perdas e danos, mais juros e atualização monetária segundo índices oficiais regularmente estabelecidos, e honorários de advogado" (BRASIL, 2002). É importante que se destaque que a obrigação pode ser legal ou contratual, o que significa dizer que a distinção entre obrigação e responsabilidade também incide na responsabilidade extracontratual, embora talvez seja mais facilmente identificável na responsabilidade contratual. Em último caso, na responsabilidade extracontratual, sempre haverá a obrigação de a ninguém lesar - neminem laedere. Também se pode pensar, como 
faz Cavalieri Filho (2014), na obrigação de indenizar, surgida da prática de um ilícito, seja contratual ou extracontratual ${ }^{2}$.

\section{PRESSUPOSTOS DA RESPONSABILIDADE CIVIL}

Tema bastante intrincado dentro do campo da responsabilidade civil é o da identificação de seus pressupostos. Enquanto, para alguns, são três os pressupostos da responsabilidade civil: (a) ato ilícito; (b) dano e (c) nexo causal; para outros, o ato ilícito deve ser qualificado de culpável, havendo, ainda, quem coloque a culpa como um quarto pressuposto. A colocação da culpa como pressuposto da responsabilidade civil esbarra em um problema bastante evidente: a responsabilidade objetiva, que não depende de culpa. Mais adequada parece a linha defendida por Monteiro, Maluf e Silva (2010), de que os pressupostos da responsabilidade civil são apenas os três acima mencionados: ato ilícito, dano e nexo de causalidade. A culpa, ao lado do risco, é fundamento da responsabilidade civil, como já defendia Alvim (1980), ao falar em responsabilidade que se funda na culpa. Ato ilícito, dano e nexo causal são pontos que sempre terão que ser cumulados, para que se possa falar em responsabilidade civil, seja objetiva ou subjetiva, contratual ou extracontratual. Por outro lado, a culpa nem sempre é imprescindível, razão pela qual poderia ser vista como um pressuposto da responsabilidade subjetiva, mas jamais como pressuposto de toda e qualquer responsabilidade.

Cavalieri Filho (2014) adota um elenco diferente de pressupostos, conforme se trate de responsabilidade extracontratual ou contratual, sendo que, nesta última, o autor coloca como pressupostos (a) a existência de contrato válido; (b) a inexecução do contrato; (c) o dano e (d) o nexo causal. Essa diferenciação, no entanto, não será adotada no presente trabalho, por se entender que os dois primeiros (contrato válido e inexecução) estão abrangidos na ideia de ato ilícito.

\subsection{O ato ilícito}

\footnotetext{
2 "Atentando, todavia, para a distinção existente entre obrigação e responsabilidade, seria mais correto dizer que o ato lícito é fonte das obrigações (dever originário), enquanto o ato ilícito é fonte da responsabilidade (obrigação sucessiva, consequente ao descumprimento da obrigação originária)", reconhece o próprio Cavalieri Filho (2014, p. 26).
} 
A ideia de ato ilícito começou a ser trabalhada no BGB alemão de 1897, primeira legislação a substituir os conceitos de delito e quase-delito pelo conceito de ato ilícito, como aponta Dantas (1979).

O ato ilícito, diz Cavalieri Filho (2014), é o conceito de maior importância para o estudo e compreensão da responsabilidade civil, porque é seu fato gerador. Toda responsabilidade pressupõe ato ilícito. Por isso, disse-se que não parece correto dizer que o ato ilícito é pressuposto da responsabilidade extracontratual, enquanto a existência de contrato válido e sua inexecução seriam pressupostos da responsabilidade contratual.

O conceito de ato ilícito, no entanto, não é consensual. Historicamente, a definição de ato ilícito, em linhas gerais, era a de um ato contrário à lei, dominável pelo agente. $\mathrm{O}$ conceito de ato ilícito, portanto, esteve ligado à ideia de culpa, como destaca Cavalieri Filho (2014). Como a culpa foi cedendo espaço à responsabilidade objetiva, esse conceito clássico, diga-se assim, de ato ilícito, passou a ser incompatível com o moderno Direito Civil. Da percepção dessa incompatibilidade, surgiram ainda mais problemas. Correntes que pretendiam a manutenção do conceito de ato ilícito passaram a defender que a responsabilidade civil sem culpa não seria verdadeira responsabilidade, mas apenas garantia, ou, então, que a responsabilidade civil objetiva derivaria de ato lícito. Tais posicionamentos, no entanto, como bem destaca Cavalieri Filho (2014), posicionaram-se na contramão da linha evolutiva da responsabilidade civil. Não é plausível cogitar de responsabilidade civil por ato lícito, muito menos dizer que a responsabilidade objetiva não é verdadeira responsabilidade. A melhor solução é a adequação do conceito de ato ilícito, tendo-se sempre em mente que a busca por um conceito absoluto, perfeito, tende ao fracasso.

Uma possível solução é levar em conta o que Cavalieri Filho (2014) chamou de duplo aspecto da ilicitude. A ilicitude poderia ser encarada sob dois pontos de vista: um objetivo e um subjetivo.

Do ponto de vista objetivo, a ilicitude corresponderia à desconformidade com o Direito. "A conduta contrária à norma jurídica, só por si, merece a qualificação de ilícita ainda que não tenha origem numa vontade consciente e livre", explica Cavalieri Filho (2014, p. 22). Não há dúvida de que a conduta contrária ao que dispõe a lei ou a convenção é ilícita, não se tornando escusável nem mesmo pela alegação de ignorância, como lembra Alvim (1980). Nesse sentido, Dantas (1979, p. 347) já definia o ato ilícito como “[...] o 
comportamento do homem que transgride um dever jurídico imposto pela lei”. O ponto essencial, aqui, é compreender que a vulneração do direito é apenas uma das facetas da ilicitude, e não ela mesma.

Se, do ponto de vista objetivo, a ilicitude é a contrariedade ao direito, do ponto de vista subjetivo, a conduta só é ilícita se consciente e livre. "O elemento subjetivo já de entrar em sua definição, visto como, em sentido estreito, ato ilícito não equivale a transgressão legal, ou a causação de dano", lecionava Gomes (1976, p. 314). Indispensável, portanto, prossegue o Autor (1976, p. 314), “[...] que o ato lesivo seja praticado livre e conscientemente, de modo a se configurar a culpa do agente". Enquanto a verificação da ilicitude objetiva se faz por meio de um juízo de fato, a verificação da ilicitude subjetiva exige um juízo de valor acerca da conduta.

Outra saída possível para a questão da superação do conceito clássico de ato ilícito é sua classificação em ato ilícito em sentido estrito e em sentido amplo, sendo ato ilícito em sentido estrito "[...] o conjunto de pressupostos da responsabilidade [...]", nas palavras de Cavalieri Filho (2014, p. 22), e ato ilícito em sentido amplo, o ato simplesmente contrário ao direito, mas não necessariamente ensejador de responsabilidade civil. De plano, vislumbra-se uma correlação entre o ato ilícito em sentido amplo e o aspecto objetivo de ilicitude, e entre o ato ilícito em sentido estrito e o aspecto subjetivo da ilicitude.

O legislador de 2002 parece ter adotado, senão uma dessas subdivisões, outra semelhante. Isso porque, como assevera Cavalieri Filho (2014), o legislador construiu, no artigo 186, um conceito de ato ilícito fundado em culpa lato sensu. Já nos arts. 187 e 927 construiu outros conceitos de ato ilícito fundados não na culpa, mas na mera contrariedade ao direito.

\subsection{O dano}

O mais importante pressuposto da responsabilidade civil é o dano.

A responsabilidade civil, como dito algumas vezes, destina-se à reparação do dano, à recolocação das partes no status quo ante. Os próprios fins da responsabilidade civil, portanto, demonstram que não se fala em responsabilidade civil se não houver dano. "Não basta o risco de dano, não basta a conduta ilícita”, comenta Cavalieri Filho (2014, p. 92). 
"Sem uma consequência concreta, lesiva ao patrimônio econômico ou moral, não se impõe o dever de reparar", conclui $(2014$, p. 92). Os dispositivos que tratam da responsabilidade civil deixam isso claro; tanto o art. 186 quanto o art. 927 condicionam a responsabilidade civil à existência de um resultado danoso. Mesmo porque, como bem observou Cavalieri Filho (2014), indenização sem dano implicaria em enriquecimento ilícito para a vítima e em pena para o agente.

Assim como acontece com o ato ilícito, o dano também não possui uma definição unanimemente - talvez sequer majoritariamente - aceita. Não à toa, à antiga divisão do dano em moral e material, acresceu-se, ao menos, uma nova modalidade: o dano estético ${ }^{3}$.

Costumeiramente, define-se o dano material como o prejuízo causado, e o dano moral como o sofrimento, o sentimento de vexame, de humilhação, etc. Uma definição, portanto, assentada nas consequências do dano, e, por isso equivocada, para Cavalieri Filho (2014). Melhor a definição trazida por Alvim (1980, p. 172), de que "[...] o termo dano, em sentido amplo, vem a ser a lesão de qualquer bem jurídico, e aí se inclui o dano moral”. Mas, se há um conceito em sentido amplo, deve haver outro em sentido estrito, e Alvim (1980) o concebe como a lesão ao patrimônio, assim entendido “[...] o conjunto das relações jurídicas de uma pessoa, apreciáveis em dinheiro" (1980, p. 172). De fato, o prejuízo, a dor, o sofrimento, são consequências do dano; este é a própria lesão ao bem jurídico patrimônio, ao bem jurídico integridade física, ao bem jurídico honra, etc. Confunde-se, como percebeu Alvim (1980), o dano com a forma de sua apreciação.

Conforme dito, o conceito de dano é subdividido, tradicionalmente, em dano moral e dano patrimonial, admitindo-se, atualmente, a inserção do dano estético nessa qualificação. No entanto, a abordagem das espécies de dano é irrelevante para o presente trabalho, cujo objetivo é outro, razão pela qual não se adentrará na análise de cada uma das modalidades de dano.

\subsection{O nexo de causalidade}

\footnotetext{
${ }^{3}$ Na realidade, como aponta Cavalieri Filho (2014), já se tem falado em dano de morte, dano sexual, dano hedonístico, e uma gama de outras modalidades específicas de dano. Todavia, a única nova modalidade que parece já ter sido realmente incorporada às ramificações do dano, é o dano estético.
} 
A presença do ato ilícito e do resultado danoso não é suficiente para a responsabilidade civil. É imprescindível que o segundo seja uma consequência do primeiro.

À primeira vista, a verificação da existência ou não de relação de causalidade entre o ato ilícito e o resultado danoso pode parecer atividade bastante simples. Trata-se, no entanto, de impressão extremamente enganosa, chegando Pereira (1997, p. 76) a dizer que o nexo causal "[...] é o mais delicado dos elementos da responsabilidade civil e o mais difícil de ser determinado".

Em primeiro lugar, é preciso não se confundir relação causal com culpabilidade. A análise da relação causal, explica Cavalieri Filho (2014), dá-se por meio de uma imputação objetiva, consistente em verificar se a conduta do agente deu ou não causa ao resultado danoso. A culpabilidade, por sua vez, depende de uma imputação subjetiva. "Apurado que a conduta do agente deu causa ao resultado, verifica-se a seguir se o agente tinha capacidade de entendimento e se podia agir de forma diferente", esclarece Cavalieri Filho (2014, p. 62), para quem a relação de causalidade deve ser o primeiro pressuposto a ser analisado.

O problema mais complexo da verificação da relação causal, no entanto, não é confundi-la com a culpabilidade, mas, sim, a existência, não raramente, de uma concorrência de causas, ou, nas palavras de Cavalieri Filho (2014, p. 63), de uma "[...] causalidade múltipla, isto é, quando há uma cadeia de condições, várias circunstâncias concorrendo para o evento danoso, e temos que precisar qual dentre elas é a causa real do resultado".

Para auxiliar na identificação de qual das concausas seria indispensável ao resultado, algumas teorias surgiram, dentre as quais, duas se destacam, principalmente por serem antagônicas. "Enquanto uma generaliza as condições, a outra as individualiza ou qualifica”, comenta Cavalieri Filho (2014, p. 63). São, respectivamente, as teorias da equivalência das condições e da causalidade adequada.

Para a teoria da equivalência das condições, também chamada de teoria da equivalência dos antecedentes ou da conditio sine qua non, todas as situações que concorrem para a produção de determinado resultado são causas dele. "A sua equivalência resulta de que, suprimida uma delas, o dano não se verificaria", comenta Alvim (1980, p. 345). A experiência revela que muito dificilmente se estará diante de uma situação onde, 
retirada qualquer concausa, o resultado não se verificaria, o que inviabiliza a aplicabilidade dessa teoria. Além disso, nivelar todas as concausas conduz a uma cadeia infinita de nexo causal, como no exemplo trazido por Gonçalves (2014), do homicídio, em que se poderia responsabilizar o fabricante da arma, pois, sem a arma, não teria havido o ilícito. Por isso é que, em contraposição à teoria da equivalência das condições, desenvolveu-se a teoria da causalidade adequada, onde se pergunta se "[...] tal relação de causa e efeito existe sempre, em casos dessa natureza, ou existiu nesse caso, por força de circunstâncias especiais?" (ALVIM, 1980, p. 345). Se a relação de causa e efeito sempre existir, tem-se a causalidade adequada. Essa teoria, embora mais plausível do que a anterior, também revela uma certa inviabilidade, porque não há qualquer parâmetro para decidir qual das concausas é mais adequada ao resultado.

Muito embora as duas teorias mencionadas sejam as de maior destaque, ambas esbarram em obstáculos dificilmente superáveis, conforme dito. Por isso é que o legislador do Código Civil se filiou a uma terceira corrente, de aplicabilidade mais concreta, mais palpável, chamada por Gonçalves de uma amálgama das duas teorias anteriores. É a teoria dos danos diretos e imediatos, prestigiada no art. 403, do Código Civil, em que se estabeleceu que “[...] as perdas e danos só incluem os prejuízos efetivos e os lucros cessantes por efeito dela direto e imediato [...]" (BRASIL, 2002). Exige-se, portanto, que entre o ato ilícito e o resultado danoso haja uma relação de causa e efeito direta e imediata $^{4}$. Embora a expressão 'imediata' sugira uma análise temporal, não é esse o seu significado. Dano direto e imediato, explica Alvim (1980), é todo aquele que decorre do ato ilícito, sem ser interrompido por outros fatos que rompam o nexo causal. Não se trata, portanto, de uma questão necessariamente temporal. Por isso é que o motorista que causa um acidente não é responsável pelos danos que a vítima venha a sofrer em razão de erro do médico que a atendeu, por exemplo. Também por força dessa teoria é que não é indenizável a expectativa de direito; porque ela não guarda relação de causa e efeito direta e imediata, com o ato ilícito. Até a ocorrência do evento esperado, este poderia não ocorrer por inúmeras outras razões.

\section{OS FUNDAMENTOS DA RESPONSABILIDADE CIVIL}

\footnotetext{
${ }^{4}$ Discordam, pontualmente, Medina e Araújo (2014), defendendo que, exemplificativamente, no ilícito que leva a óbito um pai de família, as despesas funerárias e eventuais despesas hospitalares são danos diretos, enquanto a perda do provedor do sustento da família é um dano indireto, sendo que ambos são indenizáveis.
} 
Presentes os pressupostos da responsabilidade civil, passa-se à verificação de seus fundamentos: a culpa, em se tratando de responsabilidade subjetiva, e o risco, quando a responsabilidade é objetiva (MONTEIRO, MALUF e SILVA, 2010). Apesar do significativo ganho de espaço da responsabilidade objetiva, ainda predomina a responsabilidade subjetiva como regra. "O que se observa é a convivência de ambas: a teoria da culpa impera como direito comum ou a regra geral básica da responsabilidade civil, e a teoria do risco ocupa os espaços excedentes, nos casos e situações que lhe são reservados", pontua Pereira (1997, p. 273). No mesmo sentido a lição de Alvim (1980, p. 245), ao anotar que “[...] a responsabilidade objetiva não substitui a subjetiva, mas fica circunscrita aos seus justos limites”. E prossegue: “[...] a responsabilidade subjetiva subsiste, como regra, sem prejuízo da zona em que a responsabilidade objetiva impera e deve imperar". É o que se depreende da leitura do art. 927, parágrafo único, do Código Civil, que estabelece responsabilidade objetiva "[...] nos casos especificados em lei, ou quando a atividade normalmente desenvolvida pelo autor do dano implicar, por sua natureza, risco para os direitos de outrem" (BRASIL, 2002). Salvo disposição em contrário, portanto, a responsabilidade é subjetiva.

Sendo subjetiva a responsabilidade, “[...] não basta que o autor do fato danoso tenha procedido ilicitamente, violando um direito (subjetivo) de outrem ou infringindo uma norma jurídica tuteladora de interesses particulares”, explica Gonçalves (2014, p. 323). “A obrigação de indenizar não existe, em regra, só porque o agente causador do dano procedeu objetivamente mal", complementa o autor (2014, p. 323). Na responsabilidade subjetiva, é essencial que tenha havido conduta culposa do agente, isto é, ação ou omissão voluntária (dolo) ou conduta negligente ou imprudente (culpa em sentido estrito).

O que caracteriza a ação culposa stricto sensu é a possibilidade de se afirmar que o agente, podendo ter procedido de maneira diversa, de maneira capaz de evitar o dano, não o fez. "O critério para aferição da diligência exigível do agente, e, portanto, para caracterização da culpa, é o da comparação de seu comportamento com o do homo medius, do homem ideal, que diligentemente prevê o mal e precavidamente evita o perigo", diz Gonçalves (2014, p. 324). O critério para aferição da culpa, então, é objetivo. Do contrário, bastaria ao agente alegar que não previu o resultado danoso, para se esquivar da responsabilidade. Pouco importa se o agente, de fato, não previu o resultado danoso, ou, 
prevendo-o, não agiu adequadamente para evitá-lo. Importa que essa previsibilidade ou que essa ação para evitar o resultado fosse exigível do agente. Além dessa culpa, dita stricto sensu ou aquiliana, o agente também será responsável, obviamente, se agir com dolo, definido por Alvim (1980, p. 256), como a “[...] vontade consciente de violar um dever”, “[...] não sendo indispensável que o agente queira o mal alheio". Para Alvim (1980), portanto, o dolo está necessariamente na conduta, podendo estar ou não no resultado.

Mais simples é a constatação da responsabilidade civil fundamentada no risco, que é o alicerce da responsabilidade objetiva, a qual, “[...] ao invés de exigir que a responsabilidade civil seja a resultante dos elementos tradicionais [...] assenta na equação binária cujos pólos são o dano e a autoria do evento danoso" (PEREIRA, 1997, p. 269). A teoria do risco, desenvolvida na França, no final do século XIX, justifica a responsabilidade na assunção de um risco. "O fundamento da teoria objetiva consiste em eliminar a culpa como requisito do dano indenizável, ou seja, em admitir a responsabilidade sem culpa, e isso porque cada um deve responder pelo risco de seus atos", ensina Alvim (1980, p. 306-307). Inúmeras são as modalidades de risco que se identificou a partir da elaboração da teoria: risco proveito, assumido por quem tira proveito do fato lesivo; risco profissional, onde o dano é decorrente de uma atividade profissional do lesado; risco criado, quando o dano é decorrente de uma atividade arriscada, praticada pelo agente; dentre outros.

A regra, conforme dito, é a responsabilidade subjetiva. A responsabilidade objetiva, na forma do parágrafo único, do art. 927, só existe com expressa previsão legal.

\section{RESPONSABILIDADE CONTRATUAL E EXTRACONTRATUAL}

Uma das principais classificações da responsabilidade civil é a que a subdivide em contratual ou aquiliana e extracontratual, conforme o ato ilícito se consubstancie em uma violação à lei ou à convenção. Essa divisão da responsabilidade é bastante questionável. "Em qualquer das hipóteses existe uma norma de comportamento estabelecida, de um lado pela lei (em sentido genérico) e outro lado pela declaração volitiva individual”, explica Pereira (1997, p. 247). “O jus cogens, isto é, a disposição normativa, é invariável. Mas o legislador não as estabelece para todos os casos e é onde intervém o jus dispositivum, ou 
seja, as disposições em que se admitem a vontade das partes [...]", complementa Aguiar Dias (1997, p. 95). Filiam-se os autores, portanto, assim como Serpa Lopes (1964), à tese da unidade da culpa, segundo a qual o que importa, então, é a violação da norma de comportamento, e não o local onde essa norma está estabelecida.

Diz-se que o Código Civil trata da responsabilidade aquiliana nos arts. 186 e 927, enquanto a responsabilidade contratual é tratada nos capítulos que regulamentam as várias espécies de contrato (a responsabilidade contratual do transportador, por exemplo, é regulamentada na parte do Código que trata do contrato de transporte, e assim por diante). "Nisto, acompanha a generalidade das codificações mais antigas, contra as quais se manifesta a tendência das legislações modernas, inclinadas à unificação tendo em vista 0 fundamento comum da falta de diligência em relação ao direito alheio", já criticava Aguiar Dias (1997, p. 123). Ocorre que, na realidade, não há, sequer, verdadeira divisão, porque, como bem observaram Monteiro, Maluf e Silva (2010), os arts. 186 e 927 são aplicáveis, também, à responsabilidade contratual. A questão seria, simplesmente, de estruturação do Código. Daí a afirmação de Pereira (1997) de que não há distinção ontológica entre uma espécie de responsabilidade e outra, o que fica claro quando são apontadas as distinções existentes.

As duas principais distinções que se costuma apontar são com relação ao ônus da prova e à capacidade. No que concerne ao ônus da prova, enquanto na responsabilidade contratual, ao autor incumbiria somente a prova do ato ilícito, isto é, do descumprimento de disposição contratual, na responsabilidade aquiliana, recai sobre o autor o ônus probatório de todos os pressupostos e fundamentos da responsabilidade. Em primeiro lugar, é de se destacar que, no mínimo, soa estranho invocar uma regra de direito processual para justificar uma classificação de direito material. Em verdade, essa diferenciação no que tange ao ônus de prova é uma consequência, e não uma causa da divisão da responsabilidade. E, mesmo enquanto consequência, não é uma diferença substancial, mas superficial, tendo em conta que, como bem lembrou Amézaga (1938), assim como na responsabilidade contratual, na responsabilidade aquiliana, haverá situações em que não se exigirá, do autor, prova da culpa do réu, como, por exemplo, na responsabilidade por fato de coisas.

Com relação à capacidade, enquanto a responsabilidade contratual só existiria se capazes ambas as partes, na responsabilidade aquiliana, os tutores, curadores ou pais dos 
incapazes responderiam pelos danos causados. Mais uma vez, há uma confusão entre causas e consequências. Não há responsabilidade contratual quando uma das partes é incapaz, porque o contrato, nesse caso, é nulo. A questão nem é pertinente à responsabilidade civil, mas, sim, à parte do Direito Civil que se ocupa da formação do negócio jurídico.

Argumenta-se, ainda, que a responsabilidade contratual advém de um dever específico, enquanto a responsabilidade aquiliana decorre de um dever geral, e que aquela decorre da autonomia da vontade, ao passo que esta resulta de imposição legal; distinções de todo irrelevantes, inaptas a comprovar a existência de uma diferença substancial entre as espécies. Amézaga (1938) sintetizou a questão, ao observar que as diferenças apontadas só existem porque a natureza do direito violado varia. Não são, portanto, diferenças entre as espécies mesmas.

O tratamento da responsabilidade contratual e da responsabilidade aquiliana como coisas absolutamente distintas, revela-se, então, equivocado. "É certo que aquele que infringe um dever extracontratual ou contratual assume o dever de indenizar", anotam Medina e Araújo (2014, p. 591). As distinções que, de fato, existem entre uma e outra, são aspectos acidentais, nas palavras de Pereira (1997); secundários ou técnicos, nos dizeres de Serpa Lopes (1964). Não atingem o núcleo das espécies de responsabilidade, por assim dizer, tornando-as institutos distintos.

\subsection{Os juros moratórios}

Importante diferença decorrente da classificação da responsabilidade civil em contratual e extracontratual é a questão atinente ao termo inicial dos juros moratórios.

Reza o art. 398, do Código Civil: "Nas obrigações provenientes de ato ilícito, considera-se o devedor em mora, desde que o praticou" (BRASIL, 2002). Considerando-se o devedor em mora desde a prática do ato ilícito, o termo inicial da incidência de juros moratórios, consequentemente, é a data da prática do ilícito, como confirmou o STJ, ao editar a Súmula 54 ${ }^{5}$, que, apesar de editada sob a vigência do Código Civil de 1916, permanece em vigor. Por outro lado, em se tratando de responsabilidade contratual, em

\footnotetext{
${ }^{5}$ Os juros moratórios fluem a partir do evento danoso, em caso de responsabilidade extracontratual.
} 
regra $^{6}$, o termo inicial da incidência dos juros moratórios é a data da citação do devedor, na forma regrada pelo art. 405, também do Código Civil, e art. 240, do Código de Processo Civil.

Muito embora não existam, conforme dito, justificativas sólidas para o tratamento diferente entre a responsabilidade contratual e a aquiliana, sua regulamentação em partes distintas do Código Civil é puramente estrutural, e não acarreta maiores prejuízos. A questão do termo inicial dos juros moratórios, no entanto, é um problema à parte, especialmente quando, do mesmo ato ilícito, decorrer as duas espécies de responsabilidade. Imagine-se, por exemplo, a situação do empreiteiro que constrói um muro em desacordo em desatenção às normas da construção civil, e, posteriormente, o muro vem a cair, causando danos no imóvel vizinho e no imóvel do empreitante, ou, então, a situação hipotética trazida por Medina e Araújo (2014), do ônibus que, em um acidente, causa danos à pessoa que se encontra no ponto de ônibus e aos passageiros que já se encontravam no veículo. Em ambos os exemplos, o ato ilícito é um só. Mesmo assim, na ação indenizatória a ser movida pelo vizinho ou pela pessoa que se encontrava no ponto de ônibus, os juros moratórios incidirão deste a ocorrência do ato ilícito, enquanto na ação movida pelo empreitante ou pelos passageiros, os referidos encargos só incidirão a partir da citação, que pode vir a ocorrer somente muito tempo após a ocorrência do ilícito, v.g., na hipótese do réu que possui inúmeros endereços e o autor tem que diligenciar em cada um deles. Por isso é que Medina e Araújo (2014), defendem a aplicabilidade da regra do art. 398 também à responsabilidade contratual. "O art. 398 do CC fala em ato ilícito portanto, o ilícito poderá ser absoluto ou relativo"7, $\operatorname{argumentam~(2014,~p.~371),~}$ posicionando-se ao lado de Alvim Wambier (2000), que já defendia essa equiparação ainda sob o Código de 1916.

Conceber responsabilidade contratual e aquiliana como institutos merecedores de tratamento distinto, conforme dito, é equivocado. "A responsabilidade contratual, em paralelo com a responsabilidade extracontratual ou aquiliana, está sujeita aos mesmos extremos desta: a contrariedade à norma, o dano, a relação de causalidade entre uma e outra", lembra Pereira (1997, p. 249), destacando que, do ponto de vista ontológico, as

\footnotetext{
${ }^{6}$ Nas obrigações positivas e líquidas, incide o disposto no art. 397: "O inadimplemento da obrigação, positiva e líquida, no seu termo, constitui de pleno direito em mora o devedor. Parágrafo único. Não havendo termo, a mora se constitui mediante interpelação judicial ou extrajudicial" (BRASIL, 2002).

${ }^{7}$ Absolutos são os ilícitos extracontratuais, e relativos, os contratuais, na tradicional classificação de Pontes de Miranda.
} 
duas modalidades se confundem e se identificam quanto ao seu efeito principal, que é a obrigação de indenizar. Não há, portanto, justificativa plausível para que as espécies de responsabilidade sejam tratadas como coisas distintas, especialmente em um ponto de efeitos práticos significativos, como é o termo inicial da incidência dos juros moratórios. A defesa desse ponto de vista não importa, como bem destacou Alvim (1980), na pretensão de eliminar as diferenças havidas entre as espécies de responsabilidade. A responsabilidade, no entanto, é uma só, e assim deve ser tratada.

\section{A TEORIA DA IRRADIAÇÃO}

Também chamada de teoria do fato jurídico, a teoria da irradiação foi desenvolvida por Pontes de Miranda.

Por essa teoria, a eficácia jurídica resultava do percurso do seguinte caminho: em primeiro lugar, tem-se o suporte fático; sobre ele, incidirá determinada regra jurídica, o que tornará o suporte fático um fato jurídico; a partir dessa incidência de uma regra jurídica, que transportaria o suporte fático do mundo fático para o mundo jurídico, tem-se a eficácia jurídica. "A eficácia jurídica é a irradiação do fato jurídico; portanto, depois da incidência da regra jurídica no suporte fáctico, que assim, e só assim, passa a pertencer ao mundo jurídico", dizia Pontes de Miranda (1974, p. 5). "Ser fato jurídico é existir no mundo jurídico. Juridicizar-se é começar de existir jurìdicamente; isto é, dentro dêsse mundo", acrescentava (1974, p. 11). A eficácia jurídica, a que Pontes de Miranda chamou de irradiação, só existe após a formação do fato jurídico, o que ocorre com a incidência de uma regra jurídica sobre um suporte fático.

O que qualifica o fato como jurídico, e, consequentemente, determina a irradiação de efeitos que dele decorrerá, é a regra jurídica incidente. Por isso é que suportes fáticos distintos podem irradiar os mesmos efeitos. 'Pense-se no efeito ‘propriedade dos móveis' e nos fatos que o sistema jurídico fêz fatos jurídicos ('ocupação', 'caça', 'pesca', 'achada' ou 'invenção', 'descobrimento do tesouro', 'especificação', 'posse da coisa como sua durante x anos')", exemplifica Pontes de Miranda (1974, p. 5). No exemplo, há vários suportes fáticos diferentes, mas todos qualificados pela regra jurídica incidente como ensejadores de propriedade de móveis. 
Veja-se que, a partir do momento que esses suportes fáticos distintos se tornam o mesmo fato jurídico, os efeitos deles só podem ser os mesmos, porque o que está no mundo jurídico é o fato jurídico e não o suporta fático. "Assim, é incorreto enunciar-se que todo efeito jurídico tem causa em algum suporte fáctico [...]”, anota Pontes de Miranda (1974, p. 11), esclarecendo que, “[...] com essa linguagem, elide-se a incidência de regra jurídica no suporte fáctico suficiente, que determina a entrada dêsse no mundo jurídico, como fato jurídico, e elide-se a verificação de ter sido deficiente, ou não, a entrada". O que irradia efeitos é o fato jurídico e não o suporte fático.

Por isso é que, se no mesmo ato ilícito, há responsabilidade contratual em relação a um indivíduo, e responsabilidade aquiliana em relação a outro, o termo inicial dos juros moratórios não pode ser variar conforme a espécie de responsabilidade. Embora o suporte fático seja diferente (existência de contrato em relação a um, e inexistência em relação a outro), o fato jurídico é o mesmo (ato ilícito). O legislador, ao estabelecer termos iniciais diferentes para a incidência dos juros moratórios, raciocinou como se os efeitos decorressem do suporte fático, e não do fato jurídico, o que é um equívoco, do ponto de vista da teoria da irradiação. "Entre o suporte fáctico e tôda eficácia jurídica está o fato jurídico; não há relação lógica de fundamento a consequência imediata (de causação) entre o suporte fáctico e o efeito [...]”, porque, entre eles, “[...] há o elemento regra jurídica, sem cuja incidência o suporte fáctico não entraria no mundo jurídico, e a eficácia jurídica só se produz, depois, no mundo jurídico", explica Pontes de Miranda (1974, p. 95). Toda responsabilidade civil pressupõe a existência de ato ilícito. Por isso é que, muito embora o Código Civil, ao regulamentar as espécies contratuais, estabeleça eventuais especificidades, a regra que incide sobre o suporte fático, para qualificá-lo como ato ilícito, é o art. 186. Assim, se, no mesmo ato ilícito, o agente causa danos para alguém com quem mantinha relação contratual e para alguém com quem não mantinha relação contratual, não há justificativa, do ponto de vista da teoria da irradiação, para que a incidência de juros moratórios se dê em momentos distintos, num e noutro caso, porque o que importa para a eficácia jurídica é o fato jurídico (ato ilícito), e não o suporte fático (existência ou não de relação contratual).

\section{CONCLUSÃo}


A responsabilidade civil é matéria vastíssima. Seu estudo detalhado fez com que, ao longo do tempo, surgissem várias classificações, destacando-se a subdivisão da responsabilidade civil em contratual e extracontratual, subjetiva e objetiva, por fato próprio ou por fato de outrem, etc. O fato é que essas classificações surgiram para simplificar o estudo e a sistematização, e até mesmo a regulamentação da matéria; a responsabilidade civil, mesmo, é uma só. Ao contrário do que preconizam alguns autores, os pressupostos da responsabilidade são os mesmos, qualquer que seja a espécie de responsabilidade, a saber, ato ilícito, dano e nexo de causalidade. O que variará, em determinadas situações, são os fundamentos da responsabilidade, que podem ser a culpa ou o risco, conforme se trate, respectivamente, de responsabilidade subjetiva e objetiva. Mas, independentemente de ser fundada em culpa ou risco, para que haja responsabilidade civil, sempre haverá que se cumular ato ilícito, dano e nexo causal ${ }^{8}$.

Mesmo assim, o Código dispensa um tratamento diferenciado entre uma espécie de responsabilidade e outra, em determinadas situações, como, por exemplo, no termo inicial dos juros moratórios, na responsabilidade contratual ou aquiliana. $\mathrm{Na}$ responsabilidade aquiliana, diz o Código, em seu art. 398, que os juros de mora incidem desde o ato ilícito; já na responsabilidade contratual, o Código preceitua, no art. 405, que os juros incidirão a partir da citação. No mesmo sentido a disposição constante do art. 240, do Código de Processo Civil, que diz que a citação válida constitui em mora o devedor, ressalvados os arts. 397 e 398, do Código Civil, isto é, ressalvada a responsabilidade aquiliana, onde o devedor será considerado em mora desde a data da prática do ilícito.

A diferenciação, no entanto, não se justifica, à luz da teoria da irradiação, especialmente nos casos em que o agente, no mesmo ato ilícito, cause danos a pessoa com quem mantenha relação contratual e a pessoa com quem não mantenha relação contratual.

Pela teoria da irradiação, a eficácia jurídica pressupõe que se percorra um caminho. Esse caminho se inicia com o suporte fático, que sofrerá a incidência de uma regra jurídica, para, então, tornar-se fato jurídico. O que determina a entrada de um fato no mundo jurídico - que só a partir de então será um fato jurídico - é a regra incidente sobre o suporte fático. A eficácia jurídica, portanto, a que Pontes de Miranda chamou irradiação, mantém relação direta com o fato jurídico, e não com o suporte fático. Daí não se justificar

\footnotetext{
${ }^{8}$ Em situações excepcionalíssimas, como é o caso das usinas nucleares, a responsabilidade prescindirá de demonstração de nexo causal.
} 
a diferença no termo inicial dos juros moratórios, conforme se trate de responsabilidade contratual ou aquiliana. As espécies de responsabilidade estão no plano do suporte fático. Para fins de responsabilidade, não importa se o agente causador do dano firmou contrato com A, mas não firmou contrato com B. Importa o ato ilícito, e este é assim qualificado pelo art. 186, do Código Civil, independentemente de se tratar de responsabilidade contratual ou aquiliana. Assim, se, pelo mesmo ato ilícito, o agente causa danos a A e a B, o termo inicial dos juros moratórios deve ser o mesmo para ambos, porque o que importa é o fato jurídico (ato ilícito), e, no caso, o fato jurídico é um só.

\section{REFERÊNCIAS}

AGUIAR DIAS, J. de. Da responsabilidade civil. v. 1. 10. ed. Rio de Janeiro: Forense, 1997. $372 \mathrm{p}$.

ALVIM, A. Da inexecução das obrigações e suas conseqüiências. 5. ed. São Paulo: Saraiva, 1980. $430 \mathrm{p}$.

ALVIM WAMBIER, T. A. Do termo inicial para a contagem dos juros quando se tratar de ilícito contratual. Revista de Direito Privado [online], v.4, p. 159-161, out./dez. 2000.

AMÉZAGA, J. J. Responsabilidade por culpa: unidade genérica e diferenças específicas. Revista Forense, Rio de Janeiro, a. 35, v. 75, p. 75-81, jul. 1938.

BRASIL. Lei n ${ }^{\circ} 8.078$, de 11 de setembro de 1990. Dispõe sobre a proteção do consumidor e dá outras providências. Disponível em: <http://www.planalto.gov.br/ccivil_03/leis/L8078.htm> Acesso em: 07 mar. 2019.

BRASIL. Lei n 10.406, de 10 de janeiro de 2002. Institui o Código Civil. Disponível em: <http://www.planalto.gov.br/ccivil_03/leis/2002/L10406compilada.htm> Acesso em: 07 mar. 2019.

CAVALIERI FILHO, S. Programa de Responsabilidade Civil. 11. ed. São Paulo: Atlas, 2014. $641 \mathrm{p}$.

DANTAS, S. T. Programa de Direito Civil. 2. ed. Rio de Janeiro: Rio, 1979. 406 p.

GOMES, O. Obrigações. 4. ed. Rio de Janeiro: Forense, 1976. 429 p.

GONÇALVES, C. R. Direito Civil brasileiro. v. 4. 9. ed. São Paulo: Saraiva, 2014. 568 p.

GUSMÃO, P. D. de. Introdução ao Estudo do Direito. 8. ed. Rio de Janeiro: Forense, 1978. $530 \mathrm{p}$. 
JOSSERAND, L. Evolução da Responsabilidade Civil. Revista Forense, Rio de Janeiro, a. 38, v. 86, p. 548-559, abr. 1941.

LIMONGI FRANÇA, R. As raízes da responsabilidade aquiliana. Doutrinas Essenciais de Responsabilidade Civil [online], v. 1, p. 267-287, out. 2011.

MEDINA, J. M. G.; ARAÚJO, F. C. de. Código Civil comentado. São Paulo: Revista dos Tribunais, 2014. 1.312 p.

MONTEIRO, W. de B.; MALUF, C. A. D.; SILVA, R. B. T. da. Curso de Direito Civil. v. 5. 37. ed. São Paulo: Saraiva, 2010. 641 p.

NERY JUNIOR, N. Princípios do processo na Constituição Federal. 12. ed. São Paulo: Revista dos Tribunais, 2016. 464 p.

PEREIRA, C. M. da S. Responsabilidade civil. 8. ed. Rio de Janeiro: Forense, 1997. 350 p.

PONTES DE MIRANDA, F. C. Tratado de Direito Privado. v. 5. 4. ed. São Paulo: Revista dos Tribunais, 1974. 561 p.

SANTOS, M. S. dos. A responsabilidade civil extracontratual no Direito Romano: análise comparativa entre os requisitos exigidos pelos romanos e os elementos de responsabilidade civil atualmente existentes. Revista Direito em ação, Brasília, v. 10, n. 1, jan./jun. 2013, p. 13-44.

SERPA LOPES, M. M. de. Curso de Direito Civil. v. 5. 3. ed. Rio de Janeiro: Freitas Bastos, 1964. 440 p. 